\title{
Horizontal variability of bacterioplankton growth dynamics in a large lake
}

\author{
Ingeborg Reichart, Meinhard Simon*
}

Limnological Institute, University of Constance, PO Box 5560 X 913, D-78434 Konstanx, Germany

\begin{abstract}
We examined the horizontal variability of bacterioplankon growth dynamics in the western part of Lake Constance, Germany, including its northwestern fjord-like arm, Lake Überlingen. From May until September 1993, we measured depth profiles of bacterioplankton abundance and production as well as temperature and chlorophyll at 7 stations on the same day or on 2 consecutive days In addition, we examined the horizontal distribution of bacterioplankton growth with a higher areal resolution in Lake Überlingen in August 1993 and May 1994 by collecting samples from the upper $20 \mathrm{~m}$ at 10 stations on 4 occasions. In August 1994 we also measured these growth dynamics in $1 \mathrm{~km}^{2}$ in the center of Lake Überlingen by sampling 9 stations. The results show that the variability of bacterioplankton production was more pronounced than that of abundance and that the variability was always greatest in the upper $10 \mathrm{~m}$. Total horizontal variability of bacterioplankton production ranged from $<2$ to 8 -fold but in most cases remained $<3$-fold. Greatest variabilities always occurred at the transitions between different seasonal phases such as the phytoplankton spring bloom and clear-water phase or clear-water phase and phytoplankton summer bloom. On the basis of the coefficient of variation of the horizontal mean of production rates (standard error/mean) variability in the total study area and in Lake Überlingen was greater than that in $1 \mathrm{~km}^{2}$ in the center of Lake Überlingen, which was still greater than the within-sample variation. The seasonal dynamics of bacterioplankton growth were fairly similar at all 7 stations and 3- to 6-fold higher than the horizontal variability. We did not find any systematic horizontal patterns of bacterioplankton growth dynamics and there were no clear correlations to horizontal patterns of chlorophyll or temperature.
\end{abstract}

KEY WORDS: Bacterioplankton growth Horizontal variability - Large lakes

\section{INTRODUCTION}

It is well known from various studies of plankton dynamics in large pelagic ecosystems that horizontal differences exist among various sites within a given area. These differences may be systematic such as trophic on shore/off shore gradients in coastal environments like the Southern California Bight of the Pacific (Fuhrman et al. 1980, Mullin 1986), in estuarine environments (Pennock \& Sharp 1986, Wright et al. 1987) or in river plumes (Ducklow \& Kirchman 1983, ChinLeo \& Benner 1992). However, horizontal differences of plankton dynamics may also occur in areas without any obvious systematic trophic difference. The horizontal distribution of phytoplankton blooms and zoo-

- Addressee for correspondence.

E-mail: meinhard.simon@uni-konstanz.de plankton can occur in patches of a diameter of several meters to hundreds of kilometers (Powell et al. 1975, Therriault \& Platt 1981, Legendre \& Demers 1984, Mullin 1986, Wiens 1989). Reasons for the inhomogenous distribution of phytoplankton include windinduced turbulent diffusion, nutrient upwelling and subsequent differential growth, wind-induced aggregation and sinking of phytoplankton blooms, and grazing of zooplankton, which also may occur in horizontal patches (Pinel-Alloul et al. 1988).

Most studies on horizontal distributions of plankton have focused on phyto- and zooplankton (see above). Much less is known, however, about horizontal differences in bacterioplankton abundance and growth. Differences in bacterioplankton dynamics in on shore/off shore gradients in marine and estuarine environments have been shown by Fuhrman et al. (1980), Ducklow \& Kirchman (1983), and Kirchman et al. (1989). Güde 
(1990) reported an on shore/off shore gradient of bacterioplankton growth in Lake Constance, Germany. Heinänen \& Kuparinen (1991), Kuuppo-Leinikki (1993), and Scavia \& Laird (1987) studied the horizontal variability of bacterioplankton growth in the Baltic Sea and Lake Michigan (USA), respectively. Trousselier et al. (1993) examined the impact on wind-induced mixing on bacterioplankton growth in a Mediterranean lagoon. There is no study available, however, in which the horizontal variability of bacterioplankton growth in large lacustrine ecosystems has been studied systematically in different seasons.

It is important to study the horizontal variability of plankton dynamics in particular in large lacustrine ecosystems with pronounced physical water movements. Bacterioplankton dynamics dppeat to be particularly attractive for such studies because the abundance of the minute and buoyant bacterial cells is a good tracer of the advection of a given water body and the growth dynamics respond fairly quickly to possible horizontal variations in primary production and phytoplankton biomass. Prealpine Lake Constance exhibits pronounced water movements between the main lake (Obersee; Fig. 1) and the fjord-like northwestern part (Lake Überlingen). During the stratified season windinduced internal waves occur regularly in Obersee with amplitudes of several meters and a frequency of $4 \mathrm{~d}$. They are enhanced to an amplitude of more than $20 \mathrm{~m}$ due to a channeling effect when they enter Lake Überlingen and lead to horizontal water advection of several kilometers (Zenger et al. 1990). The potential impact of these advections on plankton dynamics can result in a change of up to 2 -fold in phytoplankton biomass at a given depth without any net growth or loss (Gaedke \& Schimmele 1991).

We studied the horizontal and spatial distribution of bacterioplankton abundance and growth and of chlorophyll in Lake Constance in its northwestern fjordlike Lake Überlingen and the western part of Obersee from May to September in order to assess patterns in the horizontal distribution of plankton dynamics. The assessment of such patterns is particularly important because many studies on plankton dynamics in Lake Constance during the last decade have been carried out at only 1 site (Stn $A_{i}$ Fig. 1) in the central part of Lake Überlingen (Simon \& Tilzer 1987, Tilzer \& Beese 1988, Weisse et al. 1990, Müller et al. 1991. Gaedke 1993).

\section{MATERIALS AND METHODS}

Study area and sampling. Lake Constance is a large $\left(539 \mathrm{~km}^{2}\right.$ ) and deep (max. depth $254 \mathrm{~m}$, mean depth $95 \mathrm{~m}$ ), warm monomictic and mesotrophic lake with a water retention time of $4.1 \mathrm{yr}$. The northwestern fjordlike part, Lake Überlingen, has a maximum and mean depth of 147 and $81 \mathrm{~m}$, respectively, and is separated from the main part by a sill of only $100 \mathrm{~m}$. The main tributary of the whole lake is the Rhine, which flows in at the easternmost part and supplies $2 / 3$ of the water inflow. However, it has little impact on the water movements in the lake, which are mainly windinduced (Zenger et al. 1990, Schimmele 1993).

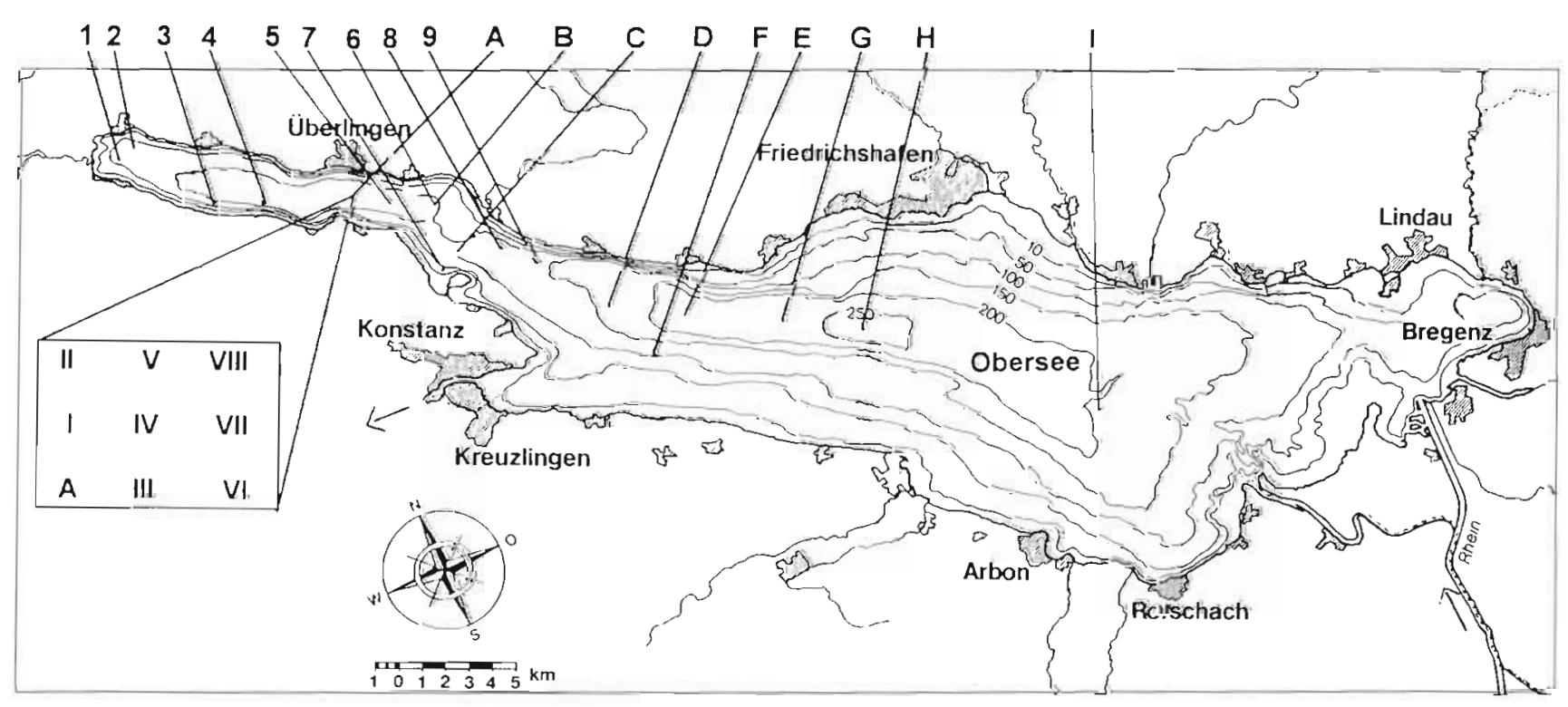

Fig. 1 Map of Lake Constance (Lake Überlingen, Obersee) and location of the sampling stations 
Water samples were collected in pre-rinsed 10 I van Dorn bottles at 7 pelagic stations (Stns A to G) in Lake Überlingen and the western part of Obersee in weekly intervals between May and July and in late August and early September 1993 (Fig. 1, Table 1). Stn A was sampled weekly between mid-April and September Due to logistic constraints, the 4 sites in Lake Überlingen were usually sampled $1 \mathrm{~d}$ before the 3 sites in the western part of Obersee. However, on 24 May and 3 June all 7 sites were sampled on the same day. In addition, 3 profiles at 2 further stations (Stns $\mathrm{H}$ and $\mathrm{I}$; Fig. 1, Table 1) were sampled in Obersee including the location of the maximum depth on 18 May, 1 June and 6 July. Samples were taken at 4 to 5 depths in the upper $20 \mathrm{~m}$ and at 3 to 8 depths below $20 \mathrm{~m}$ and $3 \mathrm{~m}$ above the sediment. Sampling was done usually between 09:00 and 12:00 h and finished within 2 h. On 3 and 9 August 1993 and on 9 and 16 May 1994 a special survey in Lake Überlingen was carried out in which 10 locations covering this whole section were sampled (Stns 1 to $4, A, 5$ to 9 ; Fig 1, Table 1). In these surveys sampling was done between 09:00 and 12:00 h from 3 boats and terminated within $2 \mathrm{~h}$. Mixed samples from $0-4,4-8$ and 8-20 $\mathrm{m}$ were taken with a $2 \mathrm{~m}$ long plexiglass tube (10 $\mathrm{cm}$ diameter) such that the whole upper $20 \mathrm{~m}$ of the water column was covered. On 2 and 9 August 1994 an area of $1 \mathrm{~km}^{2}$ at the routine sampling station of the Limnological Institute at the center of Lake Überlingen (Stn A) was sampled in the same time frame as indicated above by collecting mixed water samples from $0-4,4-8$ and $8-20 \mathrm{~m}$ from 9 stations close to Stn A (Stns A and I to VIII; Fig. 1). At each sampling site subsamples were withdrawn into 11 polyethylene bottles and kept in a cooling box in the dark until further processing in the lab, usually within $3 \mathrm{~h}$

Chlorophyll, temperature. Chlorophyll a (chl a) concentrations at Stn A were determined spectrophotometrically after hot ethanol extraction according to Simon \& Tilzer (1987). Continuous profiles of temperature and autofluorescence of chl a were taken as vertical casts to a depth of $95 \mathrm{~m}$ by a combined temperature-fluorescence-turbidity sensor (Meerestechnik Elektronik, Trappenkamp, Germany). Calibration tests with spectrophotometric measurements of extracted chl a revealed that the fluorescence sensor underestimated chl a by 10 to $30 \%$ (H. P. Grossart unpubl. data).

Bacterial abundance. Subsamples for bacterial abundance were fixed with $2 \%$ formalin (final concentration) and stored at $4^{\circ} \mathrm{C}$ until further processing. Bacterial numbers were enumerated after staining with 4'6'-diamidino-2-phenylindol (DAPI) on black $0.2 \mu \mathrm{m}$ Nuclepore filters by epifluorescence microscopy according to Porter \& Feig (1980).
Table 1. Depths of Stns A to I and 1 to 9

\begin{tabular}{|lc|cc|}
\hline Stn & Depth $(\mathrm{m})$ & Stn & Depth $(\mathrm{m})$ \\
\hline A & 147 & 1 & 60 \\
B & 100 & 2 & 60 \\
C & 100 & 3 & 95 \\
D & 155 & 4 & 100 \\
E & 220 & 5 & 90 \\
F & 100 & 6 & 70 \\
E & 247 & 7 & 22 \\
H & 254 & 8 & 100 \\
I & 197 & 9 & 130 \\
\hline
\end{tabular}

Bacterial production. During the investigations at Stns A to I and 1 to 9 in 1993 and May 1994 bacterial production was measured by the incorporation of ${ }^{14} \mathrm{C}$ leucine (Kirchman at al. 1985, Simon \& Azam 1989) as described in Simon \& Rosenstock (1992). Briefly, subsamples of $5 \mathrm{ml}$ ( 3 replicates, 1 blank) were labelled with $30 \mathrm{nM}$ (final concentration) of ${ }^{14} \mathrm{C}$-leucine (317 $\mathrm{mCi} \mathrm{mmol}^{-1}$, Amersham) and incubated at in situ temperature in the dark for $1 \mathrm{~h}$. Thereafter they were filtered onto $0.45 \mu \mathrm{m}$ nitrocellulose filters (Sartorius, Göttingen, Germany) after ice-cold extraction with $5 \%$ trichloroacetic acid (TCA) and radioasssayed. Leucine incorporation was converted into biomass production assuming an isotope dilution factor of 2 . The coefficient of variation ( $\mathrm{CV}=$ standard deviation $/$ mean) of the triplicate measurement usually was $<0.15$.

During the survey of the area around Stn A on 2 and 9 August 1994 bacterial production was measured by the ${ }^{3} \mathrm{H}$-thymidine (TdR) method (Fuhrman \& Azam 1980) Briefly, subsamples of $5 \mathrm{ml}$ (3 replicates, 1 blank) were labelled with ${ }^{3} \mathrm{H}$-thymidine (79 $\mathrm{Ci} \mathrm{mmol})^{-1}$, Amersham) and diluted 1:5 with nonlabelled TdR such that the final concentration was $30 \mathrm{nM}$. The samples were incubated, filtered, and radioassayed as described above. To convert $T d R$ incorporation rates into biomass produced, a conversion factor of $2 \times 10^{18}$ cells (mol TdR) ${ }^{-1}$ (Simon \& Rosenstock 1992) and a cell carbon content of $17 \mathrm{fg}$ $\mathrm{C}$ cell $^{-1}$ were used. A mean cell carbon content of $17 \mathrm{fg} \mathrm{C}$ was determined from the measured bacterial cell size and calculated volume $\left(0.061 \mu^{3}\right)$ according to Simon et al. (1990) (Reichart \& Simon unpubl. data).

Within-sample variation of bacterial production. The within-sample variation of bacterial production was determined on 10 May 1994 at Stn A during the phytoplankton spring bloom at high production rates. We expected the variability to be greatest at this time of the year. Five samples were collected separately at $6 \mathrm{~m}$ with a van Dorn bottle. Bacterial production of all 5 samples and the $\mathrm{CV}$ of the mean were determined by the leucine method as described above. 


\section{RESULTS}

\section{Horizontal variability in Lake Überlingen and Obersee during 1993}

The investigation of the horizontal dynamics of bacterioplankton growth in Lake Constance started in mid-May 1993 when the lake was already thermally stratified. At Stn A the temperature in the epilimnion within the upper $4 \mathrm{~m}$ was 15 to $16^{\circ} \mathrm{C}$ and at $6 \mathrm{~m}$ was still $12^{\circ} \mathrm{C}$ (Figs. $2 \& 3 \mathrm{~A}$ ). During June the temperature continuously increased to $>20^{\circ} \mathrm{C}$ at the surface and $18^{\circ} \mathrm{C}$ at $6 \mathrm{~m}$. The epilimnion stabilized further during July and August and reached a thickness of $8 \mathrm{~m}$ at the end of August (Fig. 3C). The peak of the phytoplankton spriny blüuñin alîeady occurrod in late $\Delta p$ pril, and in mid-May chl a had declined to $<6 \mu \mathrm{g} \mathrm{chl} \mathrm{l}^{-1}$ (Figs. $2 \& 3$ ) due to phosphorus depletion and heavy grazing by crustacean zooplankton, mainly daphnids. Intense grazing by daphnids kept phytoplankton biomass low during the clear-water phase in June. Bacterioplankton abundance and production started to increase only with the decline of the phytoplankton spring bloom and reached their annual maximum in May (Fig. 2). Bacterioplankton abundance and production were also reduced during the clear-water phase and fluctuated thereafter in summer. On 10 May 1994 during the phytoplankton spring bloom we determined the within-sample variation of bacterioplankton production of 5 samples collected sepa-

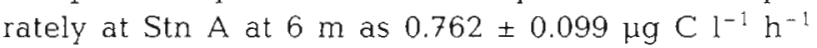
$(\mathrm{CV}=0.13)$.

On 17 May 1993 bacterial abundance and production among Stns A to D at 2 and 6 m varied up to 2 -fold even though profiles of temperature and chlorophyll looked fairly similar (Fig. 3A). Between 10 and $50 \mathrm{~m}$ vertical distribution of bacterioplankton parameters among the 4 stations was similar. This was also true below $50 \mathrm{~m}$ (data not shown). On 3 June during the early clear-water phase 7 stations were sampled on the same day. Temperature profiles were fairly similar to 17 May but chl a concentrations were substantially lower (Fig. 3B). Total variations in bacterioplankton abundance and production were also comparable to 17 May but absolute values were substantially lower. Bacterial production at Stn G between 2 and $10 \mathrm{~m}$ was substantially higher than that of the other 2 stations in Obersee but not higher than values measured in Lake Überlingen at Stns A to D. Variations in bacterial numbers were similar to 17 May but extended to a depth of $20 \mathrm{~m}$. On 25 August at Stn G chl a between the surface and $10 \mathrm{~m}$ was lower than at Stns $E$ and $F$ which was also reflected by higher bacterial numbers and reduced bacterial production at this station (Fig 3C)

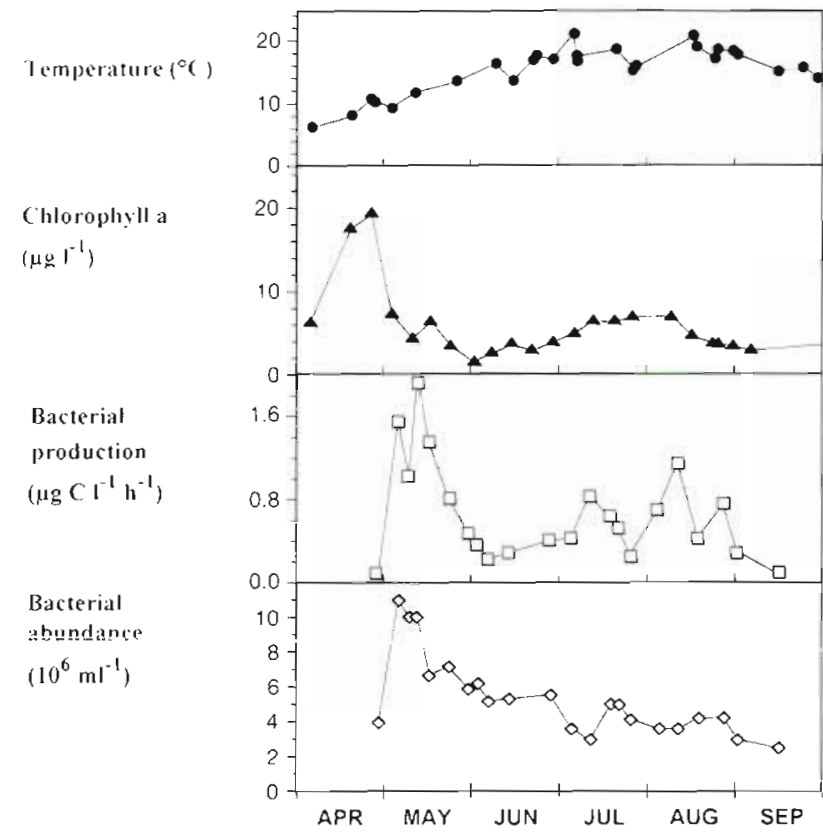

Fig. 2. Temperature, chl a, bacterioplankton production and abundance at $6 \mathrm{~m}$ depth at Stn $\mathrm{A}$ in Lake Constance between April and September 1993

In order to examine differences among various stations systematically we compared bacterial production integrated from 0 to $10 \mathrm{~m}$, the layer of the most pronounced growth dynamics at all stations and dates (Fig. 4). The seasonal dynamics of bacterioplankton growth were reflected in a fairly similar way at all stations sampled. The annual maximum occurred at most stations between 17 and 19 May. Only at Stns A and G were rates on these days not higher than the highest rates in July. At Stn A higher production rates already occurred a few days earlier (Fig. 2) which presumably was also the case at $\operatorname{Stn} \mathrm{G}$. The ratio of highest to lowest bacterial production of all stations sampled on the same day was below 2.3 except on 7 June for Stns A to D in Lake Überlingen when this ratio was 3.8 due to a low value at $\operatorname{Stn} A$. Within periods of 2 to $3 \mathrm{~d}$ the variability in bacterial production among various stations, however, also did not exceed a factor of 3. Comparing the highest and lowest bacterial production rates at individual depths of 2,6, and $10 \mathrm{~m}$ at all stations sampled at a given day total variability was always below 4.5 -fold and in $87 \%$ of the values below 2.5 -fold. Variability was greatest during the transitions from the spring bloom to the clear-water phase and from the latter to the summer situation. Seasonally, the ratio of highest to lowest bacterial production integrated from 0 to $10 \mathrm{~m}$ at 1 single station was 6 to 7 and thus at least 2 - to 3 -fold higher than horizontal variability. Seasonal differences of highest and lowest bacterial production at a single station and individual depths between 2 and $10 \mathrm{~m}$ were $>20$. 
A Temp $\left({ }^{\circ} \mathrm{C}\right) \quad \operatorname{Chl} a\left(\mu \mathrm{gl} \mathrm{I}^{-1}\right) \quad$ Bilc $\left(10^{6} \mathrm{ml}^{-1}\right) \quad \mathrm{BP}\left(\mu \mathrm{gg} \mathrm{Cl}^{-1} \mathrm{I}^{-1}\right)$
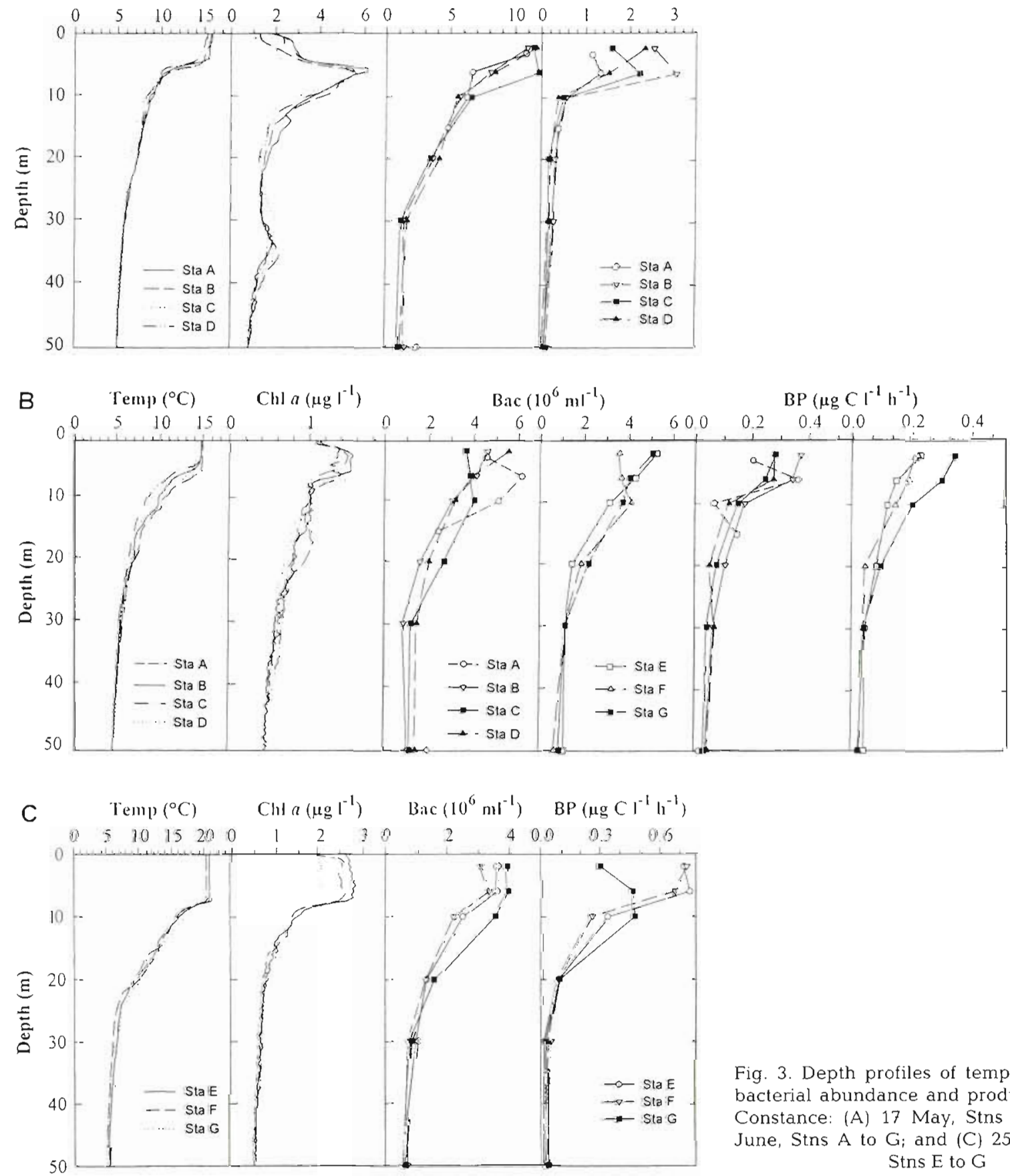

Fig. 3. Depth profiles of temperature, chl $a_{1}$ bacterial abundance and production in Lake Constance: (A) 17 May, Stns A to $D$; (B) 3 June, Stns $A$ to $G$; and (C) 25 August 1993. Stns $\mathrm{E}$ to $\mathrm{G}$

\section{Horizontal variability in Lake Überlingen in August 1993 and May 1994}

On 3 August the thermal structure at all stations was similar. The temperature from 0 to $3 \mathrm{~m}$ was $19^{\circ} \mathrm{C}$ and linearly decreased to $10^{\circ} \mathrm{C}$ at $20 \mathrm{~m}$. Maximum concentrations of chl a were $22 \mu \mathrm{g} \mathrm{chl} \mathrm{l}^{-1}$. However, its vertical distribution with maxima at 2 and $4-5 \mathrm{~m}$ varied slightly between Stns 3 and 4, A, and 5. On 9 August the maximum temperature had increased to $20.5^{\circ} \mathrm{C}$ but the thermal structure among the stations varied. At Stns 1 and 2 the epilimnion was only $2 \mathrm{~m}$ thick whereas at the others it was $4 \mathrm{~m}$. Concentrations of chl a had. decreased to $13-16 \mu \mathrm{g} \mathrm{chl} 1^{-1}$. On 3 August bacterial numbers were highest in the 8 to $20 \mathrm{~m}$ layer (Fig. 5). Total variation between the highest and lowest numbers in a given layer among the 10 stations was $<2.3$ fold (Table 2). Six days later bacterial numbers in the 


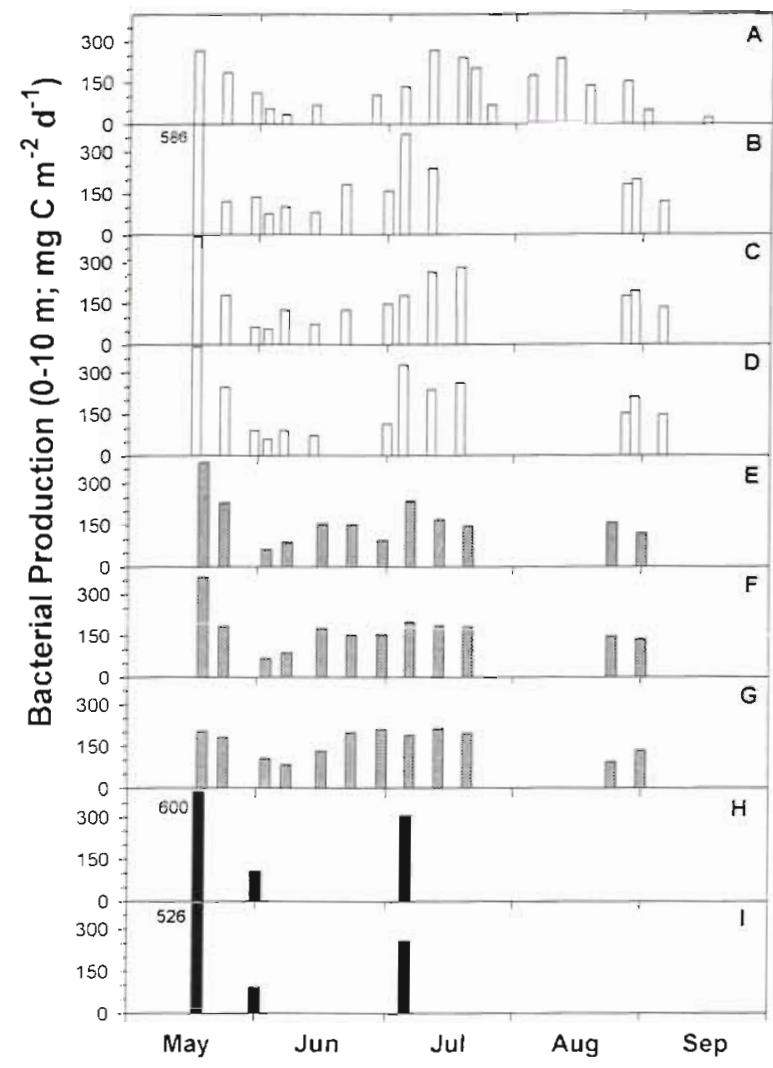

Fig. 4. Bacterial production integrated from 0 to $10 \mathrm{~m}$ at Stns A to I between May and September 1993 in Lake Constance. One fill pattern indicates sampling on 1 day. Stns $A$ to $G$, however, were sampled all together on 24 May and 3 June tion and chl a concentrations were not reflected by bacterioplankton parameters

The surveys in May 1994 were carried out at the decline of the phytoplankton spring bloorr. On 9 May a temperature of $12.5^{\circ} \mathrm{C}$ reached from the surface to $2 \mathrm{~m}$, and further below it decreased linearly to $6.5^{\circ} \mathrm{C}$ at $20 \mathrm{~m}$. On 16 May the 0 to $2 \mathrm{~m}$ layer had warmed up to $14^{\circ} \mathrm{C}$. Between 2 and $5 \mathrm{~m}$ a steep thermocline had established with a drop in temperature to $9^{\circ} \mathrm{C}$. Below, the temperature decreased to $7.5^{\circ} \mathrm{C}$ at $20 \mathrm{~m}$. Chl a concentrations at $\operatorname{Stn} \mathrm{A}$ at 0 to $4 \mathrm{~m}$ were 16.5 and $10.5 \mu \mathrm{g}$ chl $1^{-1}$ on 9 and 16 May, respectively. There were only minor differences among the various stations on both dates with a total range of 1.6- and 1.5-fold (P. Hartig unpubl. data)

On both 9 and 16 May hacterial abundance at all 3 layers was fairly similar at all stations, but numbers on 16 May were lower (Fig. 5). Total variation between the highest and lowest numbers among all stations at these 2 layers was only 1.6-fold (Table 2) and thus similar to that of chlorophyll. As in August 1993, bacterial production among the 10 stations varied more than bacterial abundance (Fig. 6). Ratios between the highest and lowest rates at a given layer were 2.2 to 2.9 on 9 May and 1.9 to 3.7 on 16 May (Table 3). On 9 May highest rates above $8 \mathrm{~m}$ were found at Stns $1, \mathrm{~A}, 5$, and 9. As in August low rates were found at $\operatorname{Stn} 7$, a shallow station quite close to the shore (Fig. 1, Table 1). On 16 May bacterial production at most stations was more than twice as high as a week before (Fig. 6). In addi-
8 to $20 \mathrm{~m}$ layer had decreased like chl a and exhibited a modified vertical pattern. Bacterial numbers were inversely distributed only at Strns 6 to 9 whereas at the others only minor differences were recorded (Fig. 5). Total variation at the different layers among the 10 stations, however, was fairly similar to the week before, ranging between 1.6- and 1.9-fold (Table 2). Bacterial production exhibited more pronounced differences than bacterial abundance with generally higher rates on 9 August as compared to $6 \mathrm{~d}$ before (Fig. 6). Low rates occurred at Stns 1, 3, and 7 on 3 August and on 9 August at Stns 7 to 9, where the inverse patterns of bacterial abundance prevailed. On 3 August total variation of bacterial production at all 3 layers among the 10 stations varied 5.3 - to 6.2 -fold (Table 3). On 9 August total variation at 0 to $4 \mathrm{~m}$ increased to 8.4 -fold whereas it decreased at 4-8 and 8-20 $\mathrm{m}$. On both dates differences in the thermal stratifica-

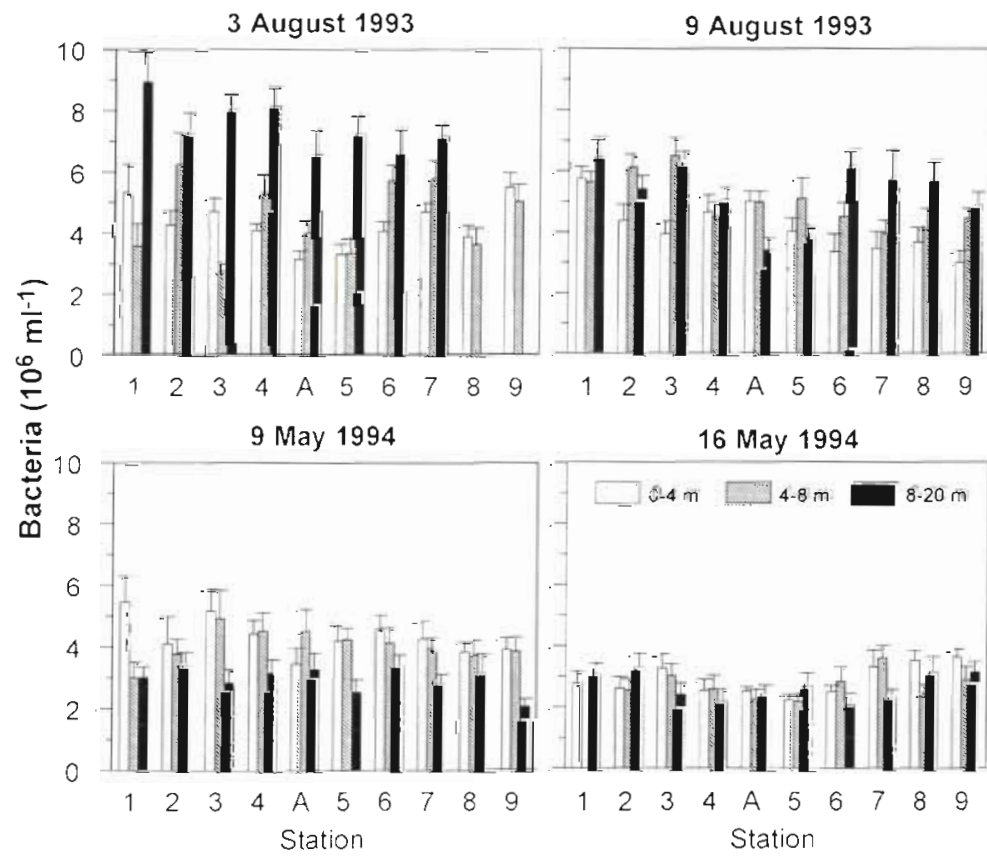

Fig. 5. Bacterial abundance at Stns 1 to 9 and A in August 1993 and May 1.994 in Lake Constance (Überlingen). Samples were taken as mean values between $0-4,4-8$, and $8-20 \mathrm{~m}$. Bars indicate standard deviation 
Table 2. Ratios of the maximum (max) over munmum (min) bacterial abundance among Stns 1 to 9 in August 1993, May and August 1994

\begin{tabular}{|c|c|c|c|c|c|c|c|c|c|}
\hline \multirow{3}{*}{$\begin{array}{l}\text { Date } \\
3 \text { Aug } 1993\end{array}$} & \multicolumn{3}{|c|}{$0-4 \mathrm{~m}$} & \multicolumn{3}{|c|}{$4-8 m$} & \multicolumn{3}{|c|}{$8-20 m$} \\
\hline & \multicolumn{2}{|c|}{$\max _{\left(10^{\mathrm{h}} \mathrm{ml}^{-1}\right)}^{\min }$} & \multirow{2}{*}{$\frac{\max / \min }{1.7}$} & \multicolumn{2}{|c|}{$\max _{\left.\left(10^{\prime \prime} \mathrm{m}\right]^{-1}\right)}^{\min }$} & \multirow{2}{*}{$\frac{\max / \min }{2.3}$} & \multicolumn{2}{|c|}{$\max _{\left(10^{h} \mathrm{ml}^{-1}\right)}^{\min }$} & $\max / \min$ \\
\hline & 5.74 & 3.17 & & 6.25 & 2.73 & & 8.95 & 6.57 & 1.4 \\
\hline 9 Aug 1993 & 5.73 & 2.99 & 1.9 & 6.49 & 3.94 & 1.6 & 6.46 & 3.88 & 1.9 \\
\hline 9 May 1994 & 5.44 & 3.45 & 1.6 & 4.91 & 2.99 & 1.6 & 3.36 & 2.03 & 1.7 \\
\hline 16 May 1994 & 3.61 & 2.21 & 1.6 & 3.58 & 2.18 & 1.6 & 3.27 & 2.06 & 1.6 \\
\hline 2 Aug 1994 & 5.93 & 2.78 & 2.1 & 3.89 & 2.20 & 1.8 & 2.66 & 1.55 & 1.7 \\
\hline 9 Aug 1994 & 7.57 & 4.02 & 1.9 & 4.73 & 3.75 & 1.3 & 2.69 & 1.58 & 1.7 \\
\hline
\end{tabular}

Table 3. Ratios of the maximum (max) over minimum (min) bacterial production among Stns 1 to 9 in August 1993 , May and August 1994

\begin{tabular}{|c|c|c|c|c|c|c|c|c|c|}
\hline \multirow[t]{2}{*}{ Date } & \multicolumn{3}{|c|}{$0-4 \mathrm{~m}$} & \multicolumn{3}{|c|}{$4-8 m$} & \multicolumn{3}{|c|}{$8-20 \mathrm{~m}$} \\
\hline & $\begin{array}{c}\max \\
(\mu \mathrm{g} C\end{array}$ & $\begin{array}{l}\min \\
\left.\mathrm{h}^{-1}\right)\end{array}$ & $\max / \min$ & $\begin{array}{l}\max \\
(\mu g C\end{array}$ & $\min _{\left.{ }^{1} \mathrm{~h}^{-1}\right)}$ & $\max / \min$ & $\max _{(\mu \mathrm{g} C}$ & $\begin{array}{l}\left.\min _{-1} h^{-1}\right) \\
\text {. }\end{array}$ & $\max / \min$ \\
\hline 3 Aug 1993 & 0.600 & 0.097 & 6.2 & 0.637 & 0.121 & 5.3 & 0.429 & 0.072 & 5.6 \\
\hline 9 Aug 1993 & 1.531 & 0.177 & 8.4 & 1.111 & 0.241 & 4.6 & 0.428 & 0.129 & 3.3 \\
\hline 9 May 1994 & 0.310 & 0.130 & 2.4 & 0.369 & 0.168 & 2.2 & 0.207 & 0.072 & 2.9 \\
\hline 16 May 1994 & 0.860 & 0.232 & 3.7 & 0.800 & 0.262 & 3.1 & 0.605 & 0.314 & 1.9 \\
\hline 2 Aug 1994 & 2.146 & 0.783 & 2.7 & 2.133 & 1.075 & 2.0 & 0.908 & 0.427 & 2.1 \\
\hline 9 Aug 1994 & 5.458 & 1.632 & 3.3 & 4.433 & 2.047 & 2.2 & 1.024 & 0.450 & 2.3 \\
\hline
\end{tabular}

tion, the horizontal and vertical pattern changed considerably. At Stns 1 to 3 rates were lowest and vertically fairly similar. At Stns $4, \mathrm{~A}$, and 5 highest rates occurred and were located in the 0 to $4 \mathrm{~m}$ layer. Also at Stns 6 to 9 rates were fairly high but maxima were located in the 4 to $8 \mathrm{~m}$ layer

Comparing all surveys in August 1993 and May 1994, no systematic differences among the 10 stations with consistently lower or higher values at a given station were found with respect to bacterioplankton abundance and production.

\section{Horizontal variability within $1 \mathrm{~km}^{2}$ around Stn A in August 1994}

On both dates only minor differences in the vertical distribution of temperature and chl a among the 9 stations occurred. On 2 August a temperature of $22^{\circ} \mathrm{C}$ ranged from the surface to $3 \mathrm{~m}$. Below it decreased exponentially to $7.5^{\circ} \mathrm{C}$ at $20 \mathrm{~m}$. On 9 August the temperature had increased to $24.2^{\circ} \mathrm{C}$ down to $2 \mathrm{~m}$ but also decreased exponentially to $7.5^{\circ} \mathrm{C}$ at $20 \mathrm{~m}$. On 2 August highest chl a concentrations of $15.5 \mu \mathrm{g}$ chl $\mathrm{l}^{-1}$ occurred at 1 to $4 \mathrm{~m}$. On 9 August chl a concentrations were only 5 to $6 \mu \mathrm{g}$ chl $1^{1}$ at 1 to $4 \mathrm{~m}$.
On 2 August horizontal and vertical patterns of bacterial abundance varied very little except at Stn A at 0 to $4 \mathrm{~m}$ where numbers were much higher (Fig. 7). Total variation within each layer at all stations was between 1.7 - and 2.1-fold (Table 2). On. 9 August bacterial abundance above $8 \mathrm{~m}$ was higher than $1 \mathrm{wk}$

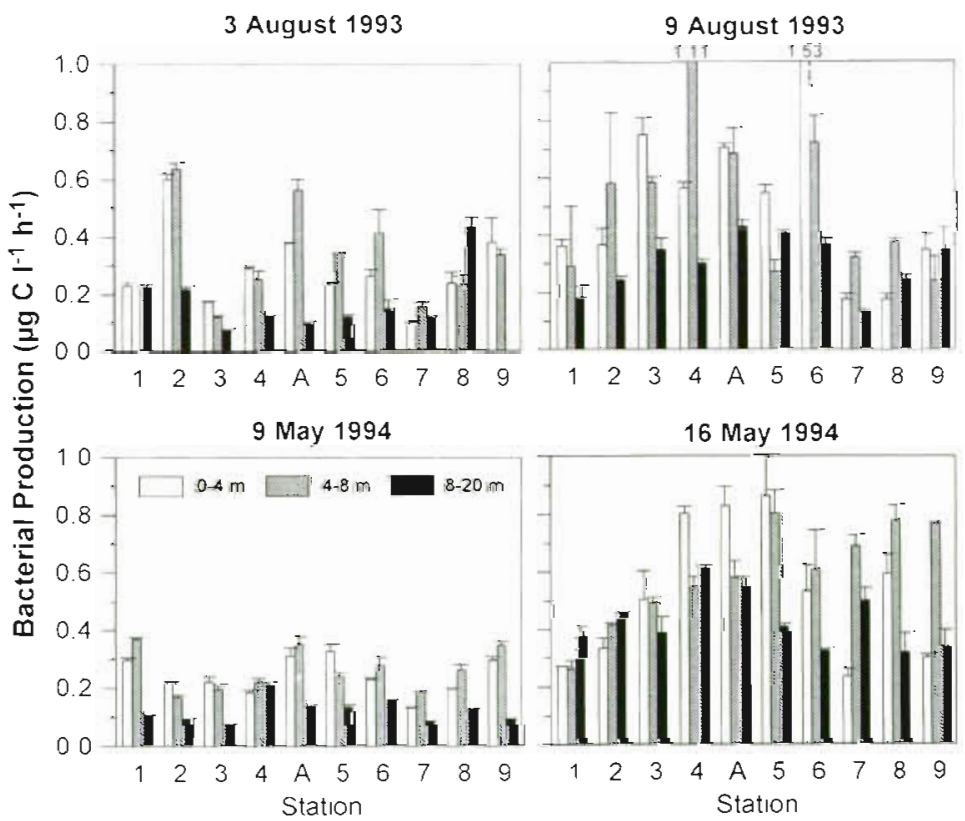

Fig. 6. Bacterial production at Stns 1 to 9 and A in August 1993 and May 1994 in Lake Constance (Überlingen). Samples were taken as mean values between $0-4,4-8$, and $8-20 \mathrm{~m}$. Bars indicate standard deviation 


\section{August 1994}

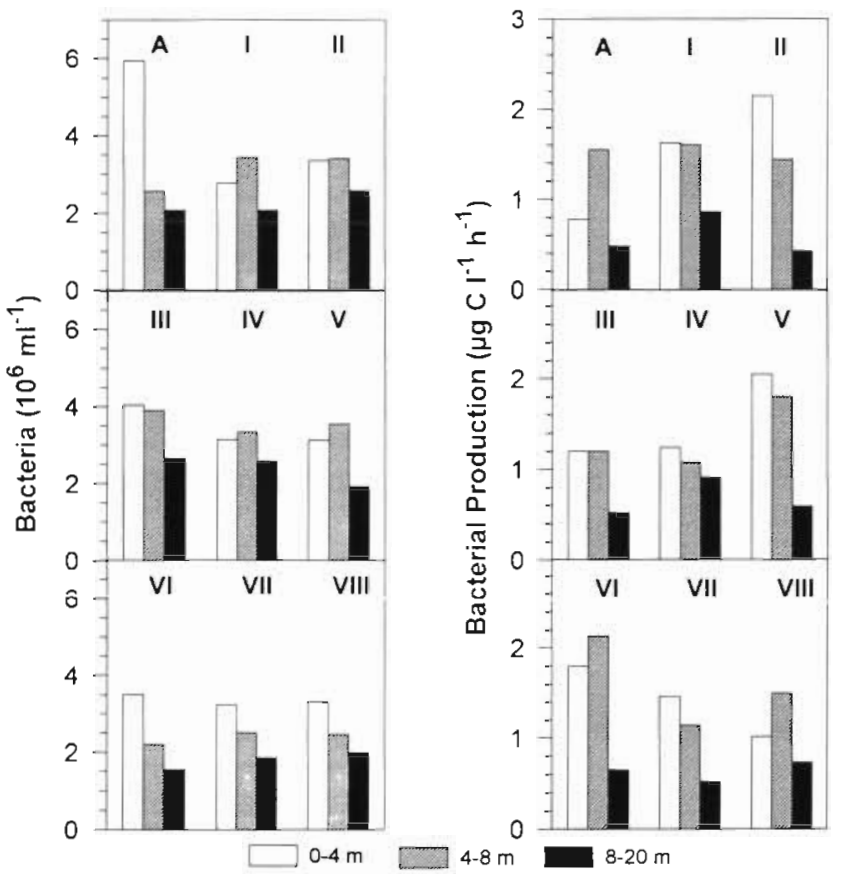

Fig. 7. Bacterial abundance and production at Stns $A$ and I to VIII on 2 August 1994 in Lake Constance (Überlingen). Samples were taken as mean values between $0-4,4-8$, and $8-20 \mathrm{~m}$

before at all stations (Fig. 8). Numbers at Stn A were still highest. Patterns of all stations except Stn III exhibited a stronger vertical decrease than a week before. The ratios of highest to lowest bacterial num-

\section{August 1994}

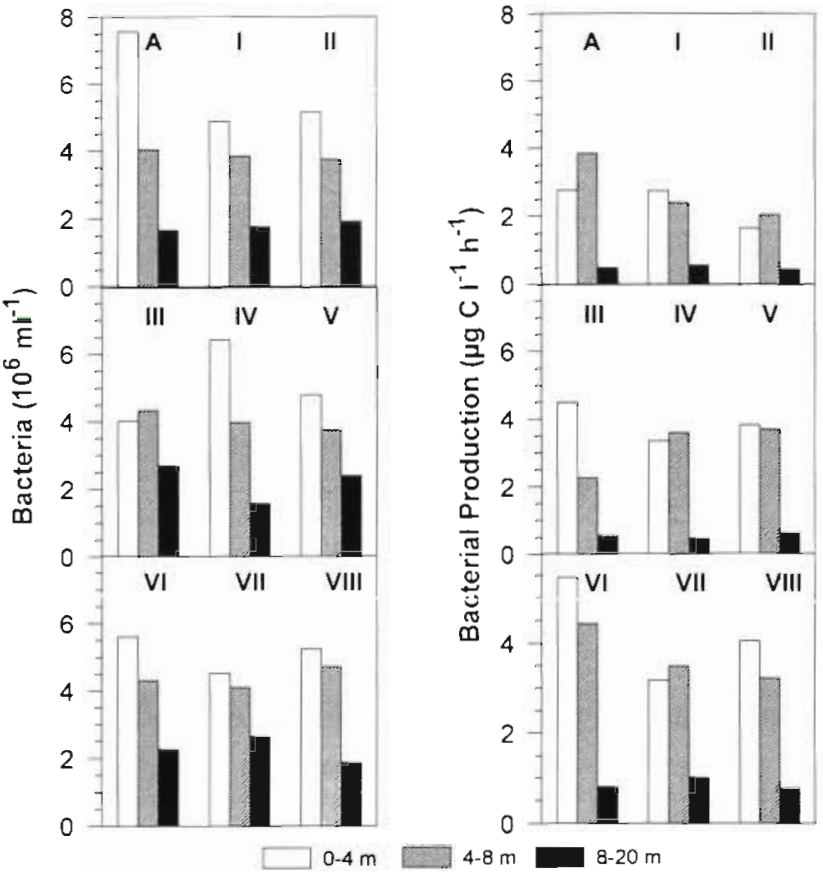

Fig. 8. Bacterial abundance and production at Stns A and I to VIIl on 9 August 1994 in Lake Constance (Überlingen). Samples were taken as mean values between $0-4,4-8$. and $8-20 \mathrm{~m}$

bers, however, were fairly similar to the previous week and ranged from 1.3 to 2.1 (Table 2). Bacterial production on 2 August varied between 2.0- and 2.7 -fold among all 9 stations (Table 3 ). Vertical patterns were

Table 4. Bacterial production in Lake Constance (Überlingen), means, standard deviation (SD), coefficients of variation (CV), and number of samples $(\mathrm{N})$. For location of stations see Fig. 1

\begin{tabular}{|c|c|c|c|c|c|c|}
\hline \multirow{3}{*}{$\begin{array}{l}\text { Date } \\
3 \text { Aug } 1993\end{array}$} & \multirow{2}{*}{$\begin{array}{c}\text { Stations } \\
1-4, A, 6-9\end{array}$} & \multirow{2}{*}{$\begin{array}{c}\begin{array}{c}\text { Depths } \\
\text { (m) }\end{array} \\
0-4\end{array}$} & \multicolumn{2}{|c|}{$\underset{\left(\mu \mathrm{g} \mathrm{Cl} \mathrm{l}^{-1} \mathrm{~h}^{-1}\right)}{\operatorname{SD}}$} & \multirow{2}{*}{$\begin{array}{l}\mathrm{CV} \\
0.48\end{array}$} & \multirow{2}{*}{$\begin{array}{l}\mathrm{N} \\
10\end{array}$} \\
\hline & & & 0.287 & 0.139 & & \\
\hline & & & 0.338 & 0.176 & 0.52 & 9 \\
\hline & & $8-20$ & 0.171 & 0.109 & 0.64 & 9 \\
\hline \multirow[t]{3}{*}{9 Aug 1993} & $1-4, A, 6-9$ & $0-4$ & 0.452 & 0.199 & 0.44 & 10 \\
\hline & & $4-8$ & 0.670 & 0.282 & 0.55 & 10 \\
\hline & & $8-20$ & 0.299 & 0.097 & 0.32 & 10 \\
\hline \multirow[t]{3}{*}{9 May 1994} & $1-4, A, 6-9$ & $0-4$ & 0.241 & 0.064 & 0.27 & 10 \\
\hline & & $4-8$ & 0.262 & 0.073 & 0.28 & 10 \\
\hline & & $8-20$ & 0.119 & 0.040 & 0.34 & 10 \\
\hline \multirow[t]{3}{*}{16 May 1994} & $1-4, A, 6-9$ & $0-4$ & 0.523 & 0.241 & 0.46 & 10 \\
\hline & & $4-8$ & 0.591 & 0.173 & 0.29 & 10 \\
\hline & & $8-20$ & 0.422 & 0.099 & 0.24 & 10 \\
\hline \multirow[t]{3}{*}{2 Aug 1994} & A, $11-I X$ & $0-4$ & 1.479 & 0.464 & 0.31 & 9 \\
\hline & & $4-8$ & 1.492 & 0.338 & 0.23 & 9 \\
\hline & & $8-20$ & 0.632 & 0.169 & 0.27 & 9 \\
\hline \multirow[t]{3}{*}{9 Aug 1994} & A. II IX & $0-4$ & 3.494 & 1.117 & 0.32 & 9 \\
\hline & & $4-8$ & 3.219 & 0.812 & 0.25 & 9 \\
\hline & & $8-20$ & 0.641 & 0.191 & 0.30 & 9 \\
\hline 10 May 1994 & A & 6 & 0.762 & 0.099 & 0.13 & 5 \\
\hline
\end{tabular}


irregular with only little correspondence to those of bacterial abundance. On 9 August bacterial production above $8 \mathrm{~m}$ was about twice as high as the previous week (Fig. 8) but variations among the lowest and highest rates remained in the same range (Table 3 ).

\section{Horizontal variability of bacterial production in Lake Überlingen}

We compared the horizontal variability of bacterial production in August 1993 and May 1994 among Stns 1 to $4, A$, and 5 to 9 with that in the $1 \mathrm{~km}^{2}$ around Stn A in August 1994 on the basis of the mean values and coefficients of variation ( $\mathrm{CV}=$ standard deviation/mean). In August 1993 the $\mathrm{CV}$ of all stations and the 3 layers studied ranged from 0.32 to $0.64 ; 5$ of 6 values, however, were $\geq 0.44$ (Table 4 ). This value was 1.5- to 2-fold higher than the CV in May 1994 which varied between 0.24 and 0.46 . The CV of the mean of the 9 stations studied in August 1994 around Stn A ranged from 0.23 to 0.32 and thus was lower than the CV of all sampling stations in Lake Überlingen studied at the same time a year earlier. The CV of the within-sample variation determined in May 1994 was only 0.13 , twice as low as that of the August survey around $\operatorname{Stn} \mathrm{A}$.

\section{DISCUSSION}

Our results show that in Lake Überlingen and the western part of Obersee of Lake Constance horizontal differences of bacterioplankton abundance and production occurred, mainly in the upper $20 \mathrm{~m}$. The differences in bacterial production were greater than those in abundance. This is not surprising because production is a much more dynamic parameter than biomass and is mainly controlled by nutrient supply (bottom up) whereas the latter is controlled additionally by losses (top down) and is thus more balanced. Horizontal differences of bacterioplankton production ranged from $<2$ - to 8 -fold but in most cases remained $<3$-fold. There was no difference between the range of values measured in Lake Überlingen and Obersee. The CV of bacterial production, however, indicated that values in $1 \mathrm{~km}^{2}$ around Stn $A$ varied less than in a greater area (Table 4). Within $1 \mathrm{~km}^{2}$ the variability of bacterioplankton production was greater than the within-sample variation as shown by the CV (Table 4). The horizontal patterns we observed did not indicate any systematic differences among stations. These observations suggest that the horizontal variability of bacterioplankton dynamics was not due to trophic differences or gradients in the area investigated but instead to other biological and physical variabilities in the pelagic zone. They are consistent with other data of the pelagic zone of Lake Constance on horizontal distributions of inorganic nutrients and zooplankton abundance (Schroeder 1994, Gries 1995) and phytoplankton abundance (R. Kümmerlin unpubl.). In contrast, a systematic decrease in phytoplankton primary production and bacterioplankton production has been found in Lake Constance in summer across the littoral to the pelagic zone (Güde 1990). This gradient presumably is due to nutrient input from the littoral zone which obviously does not affect the plankton distribution in the pelagic zone.

Our results did not indicate pronounced differences in the horizontal variability of bacterioplankton production at different seasons with respect to the whole study area. It is noteworthy, however, that the greatest variabilities among Stns A to G occurred at the transitions between seasonal phases such as spring bloom/ clear-water phase (May/June) and clear-water phase/ summer (June/July). This notion indicates that the seasonal phases of the plankton dynamics differ slightly in various parts of Lake Constance even though the general pattern including the maxima and minima of bacterioplankton biomass and production is fairly similar in all parts of the lake. This notion further confirms that the studies on bacterioplankton growth and substrate dynamics and presumably also those on general plankton dynamics carried out at Stn A in the center of Lake Überlingen are representative for whole Lake Constance (Simon \& Tilzer 1987, Tilzer \& Beese 1988, Weisse et al. 1990, Müller et al. 1991, Gaedke 1993, Simon 1994). The horizontal differences of bacterioplankton production were substantially less than its seasonal range. This observation is consistent with similar observations by Heinänen \& Kuparinen (1991) in the Baltic Sea and by Scavia \& Laird (1987) in Lake Michigan. The spatial variability, however, is in the same range as the diurnal range of bacterioplankton growth dynamics (Scavia \& Laird 1987, Simon 1994). The variability of bacterioplankton production at a single depth among all stations sampled on the same day was always greater than that of depth-integrated rates.

The absence of systematic trophic differences among the various stations raises the question of which factors are relevant to explain the observed horizontal variability of bacterioplankton growth. These factors may include biological ones such as substrate input by phytoplankton and primary production or sloppy feeding by zooplankton, and physical ones like wind turbulence, wind-induced internal seiches and the thermal structure of the lake. To examine biological factors phytoplankton and zooplankton samples were also taken at all stations dur- 
ing the surveys in Lake Überlingen in August 1993 and May 1994. Even though there was horizontal variability in the distribution of phytoplankton biomass and species composition (R. Kümmerlin unpubl. data) and zooplankton abundance (M. Simon unpubl. data) these patterns did not correlate with the horizontal patterns of bacterioplankton dynamics. It is known that phytoplankton and zooplankton occur in patches of various sizes (Powell et al. 1975, Legendre \& Demers 1984, Mullin 1986, Pinel-Alloul et al. 1988). Our observations, however, suggest that the factors affecting the horizontal distribution of phytoplankton and zooplankton did not directly control horizontal distribution of bacterioplankton dynamics either. Both groups of organisms may somewhat indirectly affect the horizonidi disiniuniuin of bacterioplankton via release of substrates by autolysis of algae and sloppy feeding by zooplankton.

There are indications, however, that physical factors also at least partially controlled horizontal dynamics of bacterioplankton growth. A direct influence of wind was probably unimportant during most of the growing season. Studies by Therriault \& Platt (1981) in St. Margaret's Bay, Nova Scotia, Canada, and by Trousselier et al. (1993) in a Mediterranean lagoon showed that wind has a direct effect on the horizontal distribution of phytoplankton biomass and bacterioplankton growth only above a speed of $5 \mathrm{~m} \mathrm{~s}^{-1}$. At Lake Constance, during the growing season an average daily wind speed of $>5 \mathrm{~m} \mathrm{~s}^{-1}$ is restricted to a few storm events early and late in the year even though. the daily maximum wind speed fairly often exceeds $5 \mathrm{~m} \mathrm{~s}^{-1}$ (Gries 1995). Growth dynamics of phytoplankton (Powell et al. 1975) and presumably also of bacteria (this study) exceeded dynamics due to turbulent diffusion induced by wind speeds $<5 \mathrm{~m} \mathrm{~s}^{-1}$. An indirect influence of wind in Lake Constance presumably is mediated by internal seiches which occur fairly regularly when the lake is stratified (Zenger et al. 1990, Schimmele 1993). The internal seiches have a mean period of $4 \mathrm{~d}$ but are overridden by oscillations of higher orders and lead to horizontal transport of water masses of several kilometers and to water exchange between Lake Überlingen and Obersee /Gaedke \& Schimmele 1991). From July until early September internal seiches are most pronounced because of the stable thermal stratification. There are some indications that the horizontal distribution of bacterioplankton abundance in Lake Überlingen in August 1993 was affected by internal seiches: (1) the range of the horizontal variability of bacterioplankton production in August 1993 was greater than in May 1994 when the thermal stratification was less stable (Tables $3 \& 4$ ); and (2) on 3 August the thermal stratification at all stations in Lake Uberlingen was fairly similar. Six days later, however, the epilimnion at Stns 1 and 2, which are close to the western end of the lake, was thinner than at the other stations and vertical decrease of temperature was steeper than at stations further east. This change suggests that some upwelling of different water masses and horizontal advection towards the Obersee due to seiching had occurred before 9 August. The chlorophyll concentration of the upwelled water masses obviously was lower but bacterial production was higher than $6 \mathrm{~d}$ earlier at Stns 1 to 6 and lower than at Stns 7 to 9 . At the latter stations vertical patterns of bacterioplankton abundance were still inverse like at all stations $6 \mathrm{~d}$ earlier. It is noteworthy, though, that temporal dynamics of bacterioplankton production within $6 \mathrm{~d}$ were higher than horizontal differences on both dates. These observations suggest that horizontal and temporal dynamics of bacterioplankton growth were controlled by a combined effect of physical and biological factors, e.g. seiching, upwelling and horizontal advection in combination with a changing substrate supply. We hypothesize that production rates responded more to biological factors such as nutrient supply as an indirect effect of upwelling, whereas bacterial abundance as a more conservative parameter reflected the advection of water masses. A further indication of a physical control by seiching of the horizontal distribution of bacterioplankton abundance on a smaller scale were the similar patterns of bacterial numbers at several stations in the $1 \mathrm{~km}^{2}$ around Stn A in August 1994 (Figs. $7 \& 8$ ). A striking result of this survey was the fact that vertical patterns of bacterioplankton abundance at Stn A were always different from the other stations. We assume that we did not wait long enough during this busy sampling program after stopping the propeller of our $22 \mathrm{~m}$ long research vessel until the ship drifted into waters unaffected by the propellerinduced mixing. Another indication of a physical control by seiching of the horizontal distribution of bacterioplankton production close to the thermocline is the notion that the $\mathrm{CV}$ of the horizontal means of bacterial production of Stns $A$ to $G$ at 15 and/or $20 \mathrm{~m}$ during the stratified period was twice as high as that above $10 \mathrm{~m}$ even though the absolute rates of bacterial production above $10 \mathrm{~m}$ were substantially higher (data not shown)

In conclusion we have shown that horizontal variation of bacterioplankton growth dynamics does exist in the pelagic zone of Lake Constance and is affected by both biological and physical factors. The variation was greatest at the transitions between 2 distinct growth phases, but at other times it was usually less than 3fold, seasonal dynamics were nearly similar in all parts of the lake studied and always greater than horizontal variations. 
Acknowledgements. We thank H. P. Grossart for providing us with data of bacterial abundance and production of $\operatorname{Stn} A$, the routine sampling site of the Limnological Institute, and $B$. Beese for spectrophotometric chl a analysus. We are indebted to the students of the limnology summer courses in 1993 and 1994 who helped enthusiastically with samplings and measurements of the specral surveys in Lake Überlingen and around Stn A in August 1993 and 1994. We are also gratef ul to all colleagues and the staff of the Limnological lnstitute who partıcipated in the special surveys an May 1994. We thank in particular the captains of the RVs 'Robert Lauterborn' and 'Tinka', and K. Wiedemann and F. Romer for their invaluable help on board. This work was funded by the Special Collaborative Program 'Cycling of Matter in Lake Constance' (SFB 248) of the Deutsche Forschungsgemeinschaft.

\section{LITERA'TURE CITED}

Chin-Leo G, Benner R (1992) Enhanced bacterioplankton production and respiration at intermediate salinities in the Mississippi River Plume. Mar Ecol Prog Ser 87:87-103

Ducklow HW, Kirchman DL (1983) Bacterial dynamics and distribution during a spring diatom bloom in the Hudson River Plume, USA. J Plankton Res 5:333-355

Fuhrman JA, Ammerman JW, Azam F (1980) Bacterioplankton in the coastal euphotıc zone: distribution, activity and possible relation with phytoplankton. Mar Biol 60:201-207

Fuhrman JA, Azam F (1980) Bacterioplankton secondary production estimates for coastal waters of British Columbia, Antarctica and California. Appl Environ Microbiol 39: 1085-1095

Gaedke U (1993) Ecosystem analysis based on biomass size distributions: a case study of a large plankton community in a large lake. Limnol Oceanogr 38:112-127

Gaedke U, Schimmele M (1991) Internal seiches in Lake Constance: influence on plankton abundance at a fixed sampling site. J Plankton Res 13:743-754

Gries T (1995) The phosphorus budget of the upper $20 \mathrm{~m}$ of Lake Überlingen (Bodensee) with special emphasis to sedimentation. PhD thesis, University of Constance (un German)

Güde $H$ (1990) Bacterial production and the flow of organic matter in Lake Constance. In: Tilzer MM, Serruya C (eds) Functional and structural properties of large lakes. Springer-Verlag, New York, p 489-502

Heinänen A, Kuparinen J (1991) Horizontal variation of bacterioplankton in the Baltic Sea. Appl Environ Microbiol 57: $3150-3155$

Kirchman D, K'Nees E, Hodson R (1985) Leucine incorporation and its potential as a measure of protein synthesis by bacteria in natural aquatic systems. Appl Environ Microbiol 49:599-607

Kirchman D, Soto Y, van Wambeke F, Bianchi M (1989) Bacterial production in the Rhône River plume: effect of mixing on relationships among microbial assemblages. Mar Ecol Prog Ser 53:267-275

Kuuppo-Leinikki P (1993) Horizontal distribution of photoand heterotrophic microorganisms on the coastal area of the northern Baltic Sea - a case study. J Plankton Res 15 $27-35$

Legendre L, Demers S (1984) Towards dynamic biological oceanography and limnology. Can J Fish Aquat Sci 41:2-19

Müller H, Pinto-Coelho RM, Schweizer A, Weisse T (1991) Seasonal succession of ciliates in Lake Constance. Microb Ecol 21:119-138
Mullın MM (1986) Spatial and temporal scales and patterns. In: Eppley RW (ed) Plankton dynamics of the Southern California Bight. Springer-Verlag, New York

Pennock JR, Sharp JH (1986) Phytoplankton production in the Delaware estuary: tomporal and spatial variability. Mar Ecol Prog Ser 34:143-155

Pinel-Allouf B, Downing JA, Perusse $M$, Codin-Blumer $G$ (1988) Spatial heterogeneity in freshwater zooplankton: variation with body size, depth, and scale. Ecology 69: 1393-1400

Portes KG, Feig YS (1980) The use of DAPI for identifying and counting aquatic microflora. Limnol Oceanogr 25: $943-948$

Powell TM, Richerson PJ, Dillon TM, Agee BA, Dozker BJ, Godden DA, Myrop LO (1975) Spatial scales of current speed and the phytoplankton biomass fluctuations in Lake Tahoe. Science 189:1088-1090

Scavia D, Laird GA (1987) Bacterioplankton in Lake Michigan: dynamics, controls, and significance to carbon flux. Limnol Oceanogr 32:1017-1033

Schimmele $M$ (1993) Induction of internal seiches in Lake Constance by wind. PhD thesis, University of Heidelberg (in German)

Schroeder S (1994) Spatial heterogeneity in the plankton of Lake Constance. Diploma thesis, University of Constance (in German)

Simon M (1994) Diel varıability of bacterioplankton biomass production and cell multiplication in Lake Constance. Arch Hydrobiol 130:283-302

Simon $M$. Alldredge AL, Azam F (1990) Bacterial carbon dynamics on marme snow. Mar Ecol Prog Ser 65:205-211

Simon M, Azam F (1989) Protein content and protein synthesis rates of marine planktonic bacteria. Mar Ecol Prog Ser 51:201-213

Simon M, Rosenstock B (1992) Carbon and nitrogen sources of planktonic bacteria in Lake Constance studied by the composition and isotope dilution of intracellular amino acids. Limnol Oceanogr 37:1496-1511

Simon M. Tilzer MM (1987) Bacterlal response to seasonal changes in primary production and phytoplankton biomass in Lake Constance. J Plankton Res 9:535-552

Therriault JC, Platt T (1981) Environmental control of phytoplankton patchiness. Can J Fish Aquat Sci 38:638-641

Tilzer MM, Beese B (1988) The seasonal productivity cycle of phytoplankton and controlling factors in Lake Constance. Schweiz Z Hydrol 50:1-39

Trousselier M, Cahet G, Lebaron P, Baleux B (1993) Distribution and dynamics of bacterial production in relation to wind perturbations in a Mediterranean lagoon. Limnol Oceanogr 38:193-201

Weisse T, Müller H, Pinto-Coelho RM, Schweizer A, Springmann D, Baldringer G (1990) Response of the microbial loop to the phytoplankton spring bloom in a large prealpine lake. Limnol Oceanogr 35:781-794

Wiens JA (1989) Spatial scaling in ecology. Funct Ecol 3: $385-397$

Wright RT, Coffin RB, Lebo ME (1987) Dynamics of planktonic bacteria and heterotrophic microflagellates in the Parker Estuary, northern Massachusetts. Cont Shelf Res 7 : 1383-1397

Zenger A, llmberger J, Heinz $G$, Schimmele M, Schlosser P, Imboden D, Münnich KO (1990) Behaviour of a mediumsized basin connected to a large lake. In: Tilzer MM, Serruya $C$ (eds) Functional and structural properties of large lakes. Springer-Verlag, New York, p 133-155

Manuscript first received: November 20, 1995

Revised version accepted: June 1, 1996 